\title{
The role of transnational dimensions in emerging economy Technological Innovation Systems for clean-tech
}

\author{
Jorrit Gosens ${ }^{\mathrm{a}, \mathrm{b}, \mathrm{c}}$, Yonglong Lu ${ }^{\mathrm{a}, ~ *}$, Lars Coenen ${ }^{\mathrm{d}, \mathrm{e}}$ \\ a State Key Lab of Urban and Regional Ecology, Research Center for Eco-Environmental Sciences, Chinese Academy of Sciences, P.O. Box 2871, \\ Beijing 100085, China \\ b Systems Analysis, SP Technical Research Institute of Sweden, SE-40022 Göteborg, Sweden \\ ${ }^{\mathrm{c}}$ Energy and Environment, Chalmers University of Technology, SE-41296 Göteborg, Sweden \\ d CIRCLE, Center for Innovation, Research and Competence in the Learning Economy, Lund University, Sölvegatan 16, S-22100 Lund, Sweden \\ e NIFU, Nordic Institute for Studies in Innovation, Research and Education, Wergelandsveien 7, N-0167 Oslo, Norway
}

\section{A R T I C L E I N F O}

\section{Article history:}

Received 22 October 2013

Received in revised form

7 August 2014

Accepted 12 August 2014

Available online $\mathrm{xxx}$

\section{Keywords:}

Technological innovation system

Clean-tech

Emerging economies

Changing global innovation

\begin{abstract}
A B S T R A C T
The 'Technological Innovation System' (TIS) framework and its system functions have become a popular analytical tool for the study of clean-tech innovation. There is increasing attention for the role of emerging economies in global clean-tech innovation, but the applicability of TIS to emerging economies cases is not entirely straightforward. A key issue is the limited geographical considerations, in particular transnational dimensions in TIS, whereas earlier perspectives on innovation in emerging economies have stressed the role of such transnational dimensions. This paper elaborates transnational TIS actornetworks and institutions, categorizes these in relation to TIS functions, and describes their potential to induce or block TIS development in emerging economies. We draw on insights from the perspectives of National Learning Systems, International Technology Transfer, and Global Production Networks for this purpose. We conclude that the potential effects of these transnational dimensions may be accurately grasped by the existing list of system functions, lending credence to its further application of the TIS framework on emerging economy case studies. Policy makers in emerging economies should recognize these transnational dimensions and seek to optimize their potential effect on domestic TIS development, taking in to consideration a realistic assessment of its role in the global TIS.
\end{abstract}

() 2014 Elsevier Ltd. All rights reserved.

\section{Introduction}

Emerging economies ${ }^{1}$ are forecasted to be responsible for the bulk of the growth in global greenhouse gas emissions over the next two decades; China in particular stands out (Fig. 1). Mitigating

\footnotetext{
* Corresponding author. Tel.: +86 10 62917903; fax: +86 1062918177 .

E-mail addresses: Jorrit.Gosens@sp.se (J. Gosens), yllu@rcees.ac.cn (Y. Lu), Lars. Coenen@circle.lu.se (L. Coenen).

${ }^{1}$ Throughout this paper we use a country grouping suggested by the World Bank (World Bank, 2011), which divides countries into four groups, being 1) advanced economies, i.e. the industrialized nations, including Australia, Canada, the EU-15, Iceland, Japan, New Zealand, Norway, Switzerland, and the United States of America; 2) emerging economies, countries with a pace of economic growth higher than that of the advanced economies or developing countries, consisting of a total of 74 countries; 3 ) major emerging economies, a subset of six emerging economies - Brazil, China, India, Indonesia, the Republic of Korea, and the Russian Federation - whose large economic size combined and especially high growth rates means that they will collectively account for more than half of all global growth by the year 2025; 4) developing economies, a group of 89 countries with a low level of economic development and low pace of economic growth.
}

climate change will require, amongst others, widespread adoption and continued development of renewable energy technologies (IPCC, 2007; OECD, 2011).

The capacity to utilize and develop technologies is intimately related with economic development. Lagging economic development is related with weaker technological capacity, whereas strong economic development indicates increasing technological capacities (Abramovitz, 1986; Carlsson and Stankiewicz, 1991; Lundvall et al., 2002; Viotti, 2002). Well-known success stories are those of Japan and the 'Four Asian Tigers', ${ }^{2}$ that managed to very rapidly transform from technologically lagging, low cost manufacturing bases into new global hubs of innovation (Freeman, 1987, 1995; Viotti, 2002). The original work on this technological 'catch-up' in

\footnotetext{
2 Japan and the 'Four Asian Tigers' (Hong Kong, the Republic of Korea, Singapore and Taiwan) were amongst the earliest emerging economies after World War II. They witnessed rapid economic growth and growing technological capacity starting in the 1950s and 1960s, and have currently reached (close to) advanced economy status (Freeman, 1987; Lall, 1996).
} 


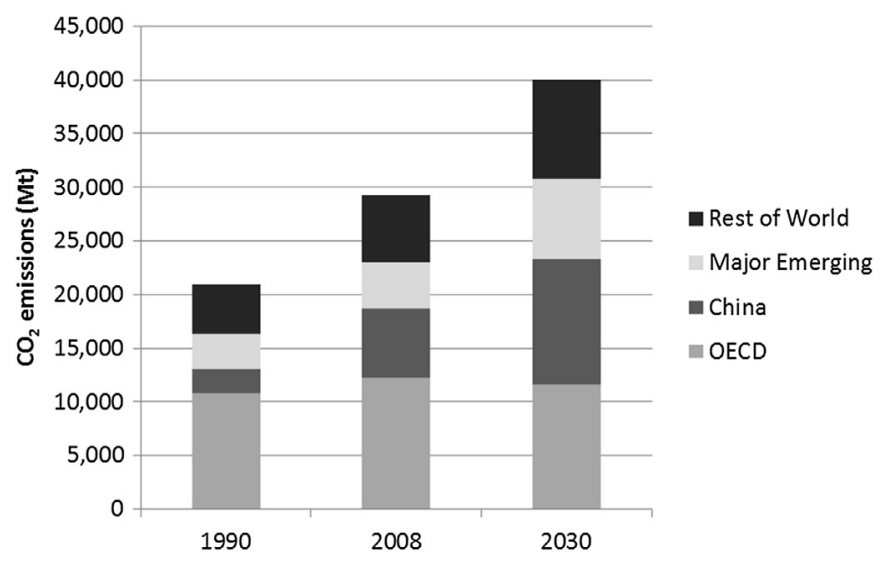

Fig. 1. GHG emissions, selected countries. Notes: emissions from fossil fuel use and cement production, metric tons of $\mathrm{CO}_{2}$-eq per year. Country grouping according to World Bank (2011), see also footnote 1; emission data from IEA (2010).

Japan and the Asian Tiger economies dealt with 'old' industries such as apparel, consumer electronics and cars. There is now increasing attention to whether or not emerging economies may replicate such a transformation in the domain of clean-tech innovation (Berkhout et al., 2010; Binz et al., 2012; Truffer, 2012; Watson and Sauter, 2011).

Clean-tech is understood here as technologies that have a reduced environmental impact, i.e., have reduced environmental emissions or natural resource use, when compared with conventional technologies in providing similar products or services (cf. OECD, 2014; Truffer, 2012). It includes a wide variety of technologies for renewable energy generation, energy efficiency and energy storage, sustainable water management, sustainable mobility, waste management, and improved resource efficiency (KPMG, 2013). Innovation is understood here as 'the generation, diffusion, and utilization of technology' (Carlsson and Stankiewicz, 1991: p. 111). Within the field of innovation studies, the literature on 'Technological Innovation Systems' (TIS) has had a strong focus on clean-tech (Jacobsson and Bergek, 2011). The geographical focus of empirical TIS work, however, has been on advanced economies (Fig. 2).

Insights from TIS work on advanced economies may not be directly applicable to emerging economies. The latecomer nature of

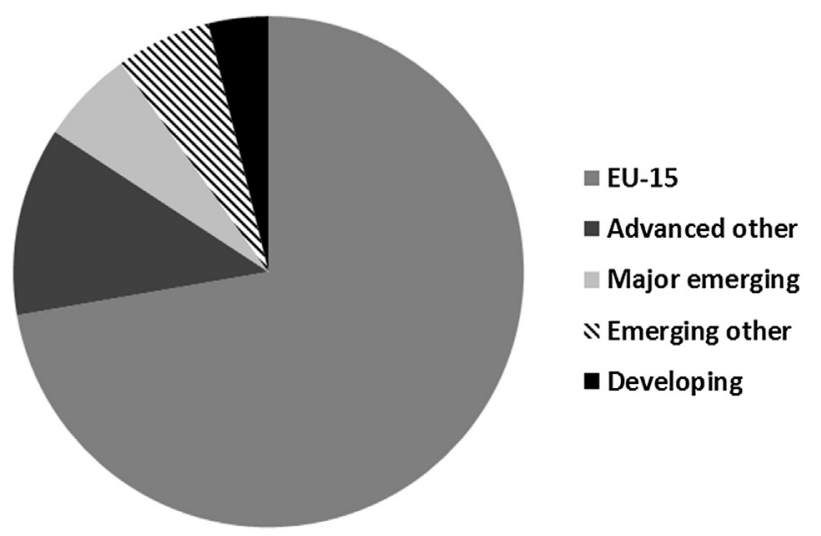

Fig. 2. Geographical focus of TIS case studies. Note: based on 187 articles using the TIS system functions framework. We searched using Google Scholar, with search terms "Technological Innovation system", and either "influence on the direction of the search" (Bergek et al., 2008b) or "guidance of the search" (Hekkert et al., 2007); names of the other functions are terms used in a much broader set of literature. Country grouping according to World Bank (2011); see also footnote 1. innovative activity in emerging economies gives reason to assume that different TIS formation mechanics may be at work. For example, the literature on technological catch-up in Japan and the Asian Tiger economies has stressed that this process was characterized by a strong reliance on foreign technologies and a highly export oriented industry complex (Archibugi and Pietrobelli, 2003; Freeman, 1987; Lundvall, 1992; Lundvall et al., 2002; Viotti, 2002). Related strands of literature, too, have stressed the transnational nature of technology and innovation, and the potential for spurring innovative activity in emerging economies as a result of increased interaction and integration with the global state-of-the-art (Ernst, 2002; Ernst and Kim, 2002; Henderson et al., 2002; Hoekman et al., 2005; IEA/OECD, 2001; Martinot et al., 1997; Ockwell et al., 2008; Worrell et al., 2001).

The TIS framework, by comparison, has been criticized for its limited consideration of geographical dimensions of innovation, and transnational dimensions in particular (Binz et al., 2014, 2012; Coenen et al., 2012). Only a limited number of TIS based studies have included explicit reference to transnational dimensions in innovation (Bai et al., 2009; Binz et al., 2014, 2012; Gosens and Lu, 2013; Hansen and Nygaard, 2013; van Alphen et al., 2008; Vasseur et al., 2013). This shortcoming puts into question the explanatory power of the TIS framework in cases where such transnational dimensions can be expected to be of significant influence, such as emerging economy cases.

The objective of this paper is to improve the applicability of the TIS framework to the study of clean-tech innovation in emerging economies, by providing a more systematic elaboration of transnational dimensions in TIS. Theoretically, we will draw from strands of literature that have more explicitly incorporated transnational dimensions into the study of innovation in emerging economies, primarily from the literature on 'National Learning Systems', 'International Technology Transfer', and 'Global Production Networks'. Empirically, we will illustrate their relevance with examples from renewable energy sectors in China.

The rest of this paper is structured as follows. In Section 2, we discuss the current lack of transnational dimensions in the TIS framework, and explain our choice of strands of literature we will draw from to improve on this. In Section 3 we elaborate these dimensions, categorize them according to TIS functions, and describe their potential effect on the development of emerging economy TIS. In Section 4 we discuss implications for policy making. Section 5 contains the conclusion and suggestions for further research.

\section{Theory and method}

Technological Innovation Systems are defined as 'dynamic networks of agents interacting [...] under a particular institutional infrastructure and involved in the generation, diffusion, and utilization of technology' (Carlsson and Stankiewicz, 1991: p. 111). In answering what enables or hampers innovation, recent TIS work has been analytically focused on TIS structure and TIS functions (key processes to form or sustain a 'well-functioning' innovation system) (Bergek et al., 2008b; Hekkert et al., 2007; see also Fig. 3).

The TIS approach aims to study innovation at the level of a technological field, and it has been argued that TIS 'may have a geographical dimension, but are often international in dimension' (Bergek et al., 2008b: p. 409). Criticizing the TIS framework for neglecting transnational dimensions may therefore appear paradoxical, as the concept has originally been suggested as an alternative to territorial innovation system concepts that depart from strict geographic boundaries (Bergek et al., 2008b; Markard and Truffer, 2008). However, although TIS have been conceptualized as transnational phenomena, the bulk of empirical TIS work has been nationally delineated (Carlsson, 2006; Coenen et al., 2012; 


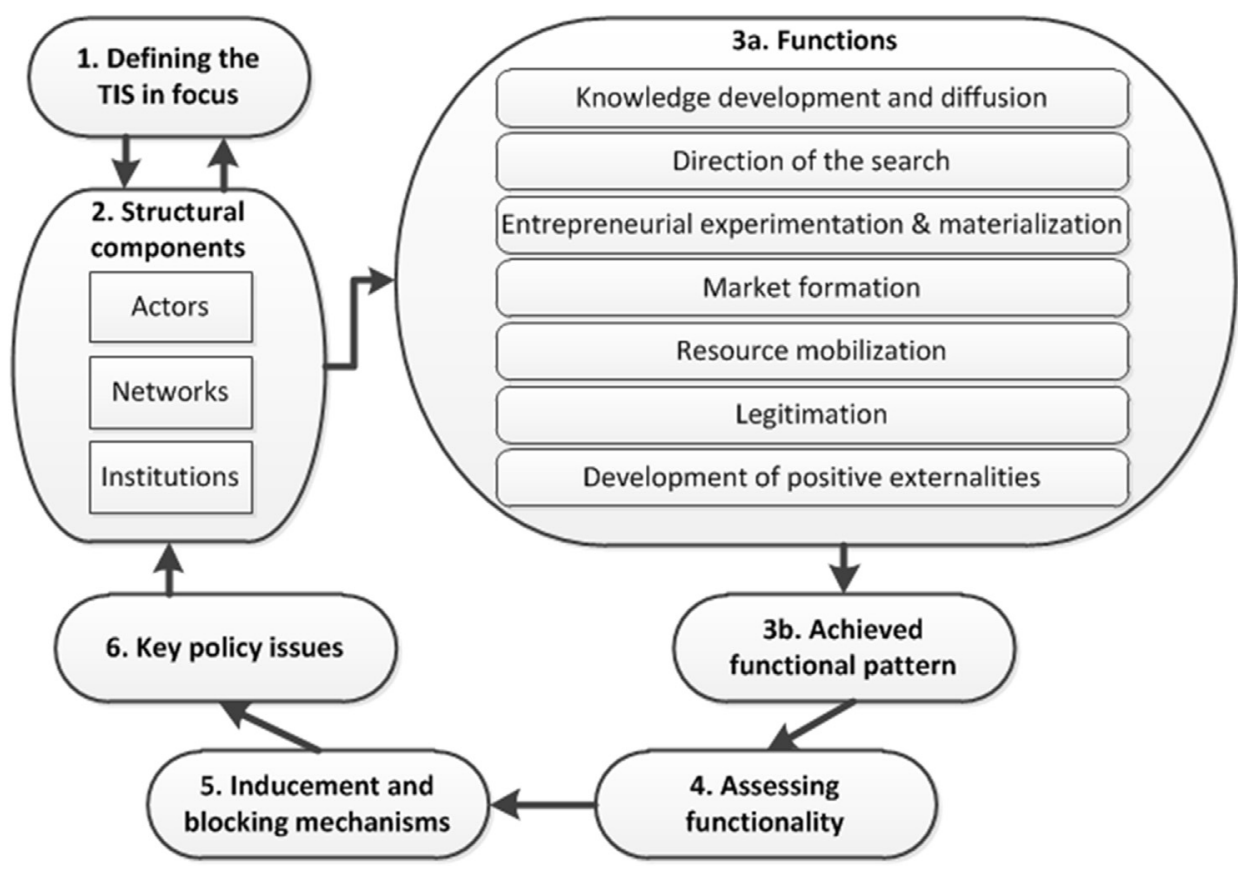

Fig. 3. The Technological Innovation Systems framework of analysis. Source: Bergek et al., 2008b.

Løvdal and Neumann, 2011). This is a problem because analysts have often conflated national borders with innovation system boundaries (Binz et al., 2014; Coenen et al., 2012).

Processes occurring at the transnational or global level have been recognized, but considered largely exogenous to the system (e.g., Suurs and Hekkert, 2009). Such system delineation may have been a permissible or justifiable limitation in much of the empirical work on advanced economies. This is true in particular because much of this work was focused on (very) early phases of TIS formation (Mohamad, 2011), in which actor-networks and market applications are relatively smaller and more localized. Furthermore, the development of such nascent systems is strongly dependent on government support and guidance, which, despite increasing transnational and global governance arrangements, remains a largely national matter. If and when transnational processes have limited influence on system development, these can be considered part of the systems' environment rather than of the system itself (cf. Markard and Truffer, 2008). Including these in the analytical scope will likely have only limited effect on the explanatory power of case studies of more embryonic innovation systems.

By contrast, the analysis of TIS formation in emerging economies would be seriously flawed by excluding transnational dimensions from the scope of analysis. By definition, late-comer countries start to participate in a certain technological field at a moment when the global TIS has matured to a certain extent. The existence of a global forefront may benefit the development of innovative activity in late-comer countries. A number of earlier perspectives on innovation in developing and emerging economies have even placed the potential interaction with this global technological forefront at the very centre of analysis (Henderson et al., 2002; Kim, 1997; Lall, 1996; Viotti, 2002).

The relative lack of attention for transnational dimensions in the TIS framework means that these are currently insufficiently elaborated for applications to emerging economy cases. In order to elaborate these dimensions, we may draw on insights from a large body of literature(s) on innovation in developing and emerging economies. Our review primarily draws from the following three strands of literature, which stand out for their strong focus on the role, and explicit transnational framing, of technology and innovation in transitional processes.

First, innovative activity in emerging economies has been a major focus in early work on National Innovation Systems that dealt with late-comer industrialization in Japan and the 'Asian Tigers' (Freeman, 1995; Nelson, 1993). These studies have argued that economic progress depended on how well these countries were able to incorporate foreign technology into the national system, and have analyzed how this 'absorptive capacity' could be improved (Cohen and Levinthal, 1990; Viotti, 2002). To highlight the foreign origin of technological knowledge, and requirement to internalize this knowledge into the domestic context, these systems have also been labelled National Learning Systems (Viotti, 2002).

Second, the literature on international technology transfer provides insight on the institutions governing transnational linkages. This strand of literature has often dealt with the global diffusion of 'environmentally sound technologies', and incorporated a strong focus on institutions and the role of government, similar to TIS (Lema and Lema, 2012; Ockwell et al., 2008). This institutional focus includes how governments of emerging economies may improve domestic circumstances to attract innovative activity from abroad, as well as how governments of technologically leading countries may stimulate and improve the outward diffusion of clean-tech to developing and emerging economies (Hoekman et al., 2005; Ockwell et al., 2008; Peltier and Ashford, 1998).

Third, we draw insights from the literature on Global Production Networks, concerning innovative capacity at the level of the firm. The central premise of this strand of literature is that economic production is seldom organized within the confines of a single firm, but rather in increasingly globalized networks of suppliers (Ernst, 2002; Henderson et al., 2002). Firms in emerging economies may benefit from the inclusion in such networks if the interaction with more technology intensive firms allows them to learn about and engage in increasingly complex and more value added production 
Table 1

TIS functions, transnational dimensions and effects on emerging economy TIS development.

\begin{tabular}{|c|c|c|c|}
\hline \multicolumn{2}{|c|}{ System function } & \multirow{2}{*}{$\begin{array}{l}\text { Affected primarily by transnational } \\
\text { dimensions in } \\
\text { - International scientific cooperation } \\
\text { - Global mobility of skilled personnel } \\
\text { - Transnational corporations } \\
\text { - Global Production Networks } \\
\text { - Global technology markets } \\
\text { - Institutional transfer programmes } \\
\text { - The World Trade Organization and TRIPS }\end{array}$} & \multirow[b]{2}{*}{$\begin{array}{l}\text { Inducement or blocking effects on TIS development } \\
\text { - Access to global pool of knowledge via collaborative research and } \\
\text { international workshops } \\
\text { - Enrolment in foreign university programmes and access to experience } \\
\text { in foreign firms or research organizations } \\
\text { - Access to global pool of IPR via knowledge transfers and spill-over from } \\
\text { transnational firm activity, firm-to-firm cooperation, mergers and } \\
\text { acquisitions, exports of equipment and technology } \\
\text { - Tensions between global pool of IPR and domestic knowledge providers } \\
\text { - Assistance with technical capacity building, improved access to technology } \\
\text { - IPR protection and infringement risks in emerging economy markets }\end{array}$} \\
\hline 1 & $\begin{array}{l}\text { Knowledge development } \\
\text { and diffusion }\end{array}$ & & \\
\hline 2 & $\begin{array}{l}\text { Influence on the } \\
\text { direction of search }\end{array}$ & $\begin{array}{l}\text { - The World Trade Organization and TRIPS } \\
\text { - Technological standards and certification } \\
\text { - Global industry platforms and } \\
\text { environmental groups }\end{array}$ & $\begin{array}{l}\text { - Domestic policy goals and preference for foreign or domestic manufacture } \\
\text { - Adherence to and certification based on clearly defined global standards } \\
\text { - Domestic needs, capabilities or technological standards and (mis)match } \\
\text { with foreign technological solutions } \\
\text { - Exchange of insights and building advocacy based on foreign experiences }\end{array}$ \\
\hline 3 & $\begin{array}{l}\text { Entrepreneurial } \\
\text { experimentation }\end{array}$ & $\begin{array}{l}\text { - Global equipment markets and } \\
\text { market competition } \\
\text { - Global technology markets }\end{array}$ & $\begin{array}{l}\text { - New market entrants from emerging economies and competition with } \\
\text { established global manufacturers } \\
\text { - Transferability and adaptability of foreign technologies to domestic } \\
\text { economic systems }\end{array}$ \\
\hline 4 & Market formation & $\begin{array}{l}\text { - Global equipment markets and } \\
\text { market competition } \\
\text { - Global technology markets } \\
\text { - The World Trade Organization and TRIPS } \\
\text { - Institutional transfer programmes }\end{array}$ & $\begin{array}{l}\text { - Competitiveness of domestic vs. foreign firms in domestic and foreign } \\
\text { markets, and regulation of cross border trade: localization quota, import } \\
\text { taxes and export subsidies, non-tariff barriers } \\
\text { - International cap-and-trade systems (for carbon emissions) }\end{array}$ \\
\hline 5 & Resource mobilization & $\begin{array}{l}\text { - Transnational corporations } \\
\text { - Private and institutional financiers } \\
\text { - Institutional transfer programmes } \\
\text { - Global mobility of skilled personnel }\end{array}$ & $\begin{array}{l}\text { - Foreign and outgoing direct investment } \\
\text { - Finance from globally active banking and investment industry } \\
\text { - Funds from GEF, World Bank, Regional Developmental Banks etc. } \\
\text { - Investment via CDM projects, CER revenue and taxation } \\
\text { - Brain drain vs. returnees, headhunting programmes }\end{array}$ \\
\hline 6 & Legitimation & $\begin{array}{l}\text { - International environmental regimes } \\
\text { - Global clean-tech race } \\
\text { - Global industry platforms and } \\
\text { environmental groups }\end{array}$ & $\begin{array}{l}\text { - Expectations on and common benefits from multilateral cooperation } \\
\text { on trans-boundary environmental issues (or resistance against it) } \\
\text { - Exchange of insights and building advocacy based on foreign experiences }\end{array}$ \\
\hline 7 & $\begin{array}{l}\text { Development of positive } \\
\text { externalities }\end{array}$ & $\begin{array}{l}\text { - Global division of labour } \\
\text { - Global clean-tech race }\end{array}$ & $\begin{array}{l}\text { - Optimal utilization of relative competitive advantages, resulting in overall } \\
\text { cost reduction and better competitiveness of technological alternative } \\
\text { - 'Sputnik moment' for clean energy; i.e. urgency to act in order to } \\
\text { ensure first mover advantages }\end{array}$ \\
\hline
\end{tabular}

steps, a process labelled 'industrial upgrading' (Ernst, 2002; Henderson et al., 2002). Such Industrial upgrading involves the use of knowledge or technology new to the firm, and can therefore also be seen as innovative activity.

Compared with TIS, the above strands of literature lack the analytical structuring and sensitivity for technology dynamics that TIS offers for analyses of clean-tech innovation. The literature on international technology transfer focuses on the utilization of technologies by economies with especially weak technological capacities and loses much of its explanatory power for phases of more advanced domestic capacity formation (Lema and Lema, 2012). The literature on National Learning Systems and Global Production Networks are more geared to that phase, but focus on industries with an existing market demand. The TIS framework has more attention for policy created markets, often a prerequisite in clean-tech innovation.

\section{Transnational dimensions of clean-tech TIS}

Here we elaborate transnational dimensions in emerging economy Technological Innovation Systems for clean-tech. We describe transnational TIS actor-networks (Section 3.1) and institutions (Section 3.2), and their potential effects on the development emerging economy TIS. A summary overview is provided in Table 1, at the end of Section 3.

It is worth noting here that clean-tech innovation and innovation systems share many characteristics with those for more general categories of technologies. Our elaboration is focused on issues pertaining to the development of clean-tech TIS in emerging economies, however. Specific to clean-tech innovation in particular are 1) a common lack of internalization of environmental cost benefits (Rennings, 2000), and concurrent lack of financial competitiveness of these technologies, and 2) a stronger dependency on government support, in terms of market stimulus, as well as in defining societal goals for a transition to future sustainable economic production systems. Specific references to clean-tech are therefore strongest in sub-sections relating to markets, and the institutions governing market formation, finance, global technology transfer and cooperation on trans-boundary environmental issues. Examples used to illustrate the relevance of these transnational dimensions throughout the text have largely been taken from empirical material specifically dealing with clean-tech innovation.

\subsection{Transnational TIS actor-networks and emerging economy TIS development}

\subsubsection{International scientific cooperation}

In systemic approaches to innovation, basic $R \& D$ is considered to be central to the process of economic change (Hekkert et al., 2007). It can be measured e.g., with the output of scientific publications, patents or $R \& D$ projects (Bergek et al., 2008b; Hekkert et al., 2007). The literature on innovation in developing and emerging economies often points to the development of 
knowledge as a relatively weak system function (Lema and Lema, 2012; OECD, 2011).

Cooperative research of scientists from different countries and exchange of results in e.g., scientific conferences, can spur the transnational development and diffusion of knowledge. For example, Binz et al. (2014) analyze transnational scientific cooperation using co-publications data in the TIS for decentralized water treatment systems. Their results suggest that the build-up of technological capabilities in this field in China was kick-started by Chinese academics tapping into global knowledge sources through a period of heightened international cooperation.

\subsubsection{Global mobility of skilled personnel}

Performing RD\&D activities requires human resources, i.e. skilled personnel. Similar to scientific cooperation, education, in particular at the university level, is strongly internationalized, and helps disseminate knowledge and skills. International university exchange programmes can help improve education levels of individuals from emerging economies (Hansen and Lehmann, 2006). Talented individuals with strong leadership and management experiences in (foreign) firms and science organizations are of high value to international competitiveness of firms, and by extension, industries and national innovation systems (Keely, 1986; Saxenian, 2005).

Problems arise when there is a net outbound migration of skilled nationals that seek employment in countries with higher salaries and better job or business opportunities. This so-called 'brain-drain' has long been recognized as an issue for developing and emerging countries (Keely, 1986; Saxenian, 2005). To help spur domestic TIS development, it is crucial that nationals return to their home countries. Experiences in the Asian Tiger economies have made clear that at some stage of economic development, living conditions, labour and business opportunities improve to a point that nationals residing abroad increasingly seek to return. The experience, education and connection with foreign knowledge clusters and business that these individuals have, may strengthen development of the domestic industry and science complex (Saxenian, 2002).

\subsubsection{Transnational corporations}

There are a number of mechanisms through which firm activity can become transnational, including market expansion (more in Sections 3.1.5 and 3.1.6) and with creation of global supplier networks (more in Section 3.1.4). Individual firms are considered transnational corporations (TNC) when these control (a stake in) entities registered in countries other than its home country (UNCTAD, 2014). This can be realized through either foreign direct investment, a subsidiary firm, joint ventures with a domestic partner or relocation decisions of manufacturing and/or R\&D activities (Brandt and Svendsen, 2006; Cantwell, 1991; Rosenberg and Frischtak, 1985). Firms organized at the transnational level may act as a vessel for intra-firm, transnational knowledge transfer (Rosenberg and Frischtak, 1985; Teece, 1977, 2001). Although debate remains on the positive effects of FDI on knowledge transfers to domestic firms (Fu et al., 2011; Kinoshita, 2000), more consensus exists on the positive effects of more cooperative, integrated forms (Blomström and Sjöholm, 1999; Ernst and Kim, 2002; Inkpen, 2000). The cooperation with or management of foreign entities increases organizational proximity, which may be as important to providing opportunities for interactive learning as is geographical proximity in technology clusters, or 'regional innovation systems' (Amin, 2002; Coe et al., 2004).

\subsubsection{Global Production Networks}

The production of technological products seldom occurs within the confines of a single firm, especially not if we consider this process to include product development (RD\&D) as well as manufacturing, marketing, distribution, maintenance etc. (Gereffi et al., 2005; Henderson et al., 2002). Firms often perform production processes cooperatively, in value chains in which each firm performs the production steps for which it has the highest levels of competitiveness (Ernst and Kim, 2002). Such 'Global Production Networks' (GPN) are typically conceptualized as being orchestrated by a lead firm (or 'flagship firm' (Ernst and Kim, 2002)). The lead firm is typically based in an advanced economy, where it derives its competency for product development from the relatively abundant availability of highly skilled labour and access to technology intensive collaboration with firms, universities and research institutes (Ernst, 2002; Henderson et al., 2002). Lead firms will seek to outsource labour intensive production steps, whilst firms based in emerging economies may use their advantageous access to low-cost labour to compete for those production steps in the GPN. Similar to transnational corporations, such production networks have the potential for transnational knowledge transfers (Ernst and Kim, 2002; Henderson et al., 2002). Lead firms tend to be very protective of their intellectual property but have to accept some dispersion of knowledge along the value chain (Ernst, 2002). Even when less sophisticated production steps are outsourced, suppliers will require manufacturing know-how and the technical quality requirements the manufacture should accord to. Supplier firms will be better capable of fulfilling those requirements when the lead firm transfers technical and managerial knowledge on the production process (Ernst and Kim, 2002). Furthermore, competition amongst suppliers is high, and suppliers in emerging economies are aware of the competitive advantages that may come from investment in managerial capabilities and workforce training (Gereffi and Fernandez-Stark, 2011). Over time, a build-up of knowledge, skills and experience in the supplier firm allows it to perform increasingly complex production steps and grasp a bigger and more profitable share of the value chain (Levy, 2008). Over longer periods of time, such 'industrial upgrading' has consequences for national economic development, with increased and more profitable firm activity, as well as increased demand for skilled, better paid labour etc. (Ernst, 2002; Gereffi and Fernandez-Stark, 2011; Henderson et al., 2002).

\subsubsection{Global equipment markets and market competition}

Increasingly globalized trade means manufacturers may attempt to find demand for their products in a larger number of markets, whilst also having to compete with a larger number of competitors, both in foreign and domestic markets. In recent years, an increasing number of emerging economies have adopted stimulus measures for clean-tech, for instance the introduction of feedin-tariffs for wind and solar energy (REN21, 2013). This has further increased global market sizes for these industries, but also increased the number of competitors in equipment manufacturing. The introduction of stimulus measures has often been motivated by both environmental and industrial policy, with governments aiming to build national industries for e.g., wind turbines and solar panels, to supply both domestic and global demand (Lewis, 2011; Lewis and Wiser, 2007).

There are particular challenges in building such national industries for emerging economies, as newly created entrants in the manufacturing industry will have to compete with well established, globally leading firms. The more matured foreign industries are able to offer superior technological quality, and are more experienced in e.g., marketing, project development, and the adaptation of their technology and services to different national market environments.

The weak competitiveness of new technological alternatives has often been pointed to in the literature on clean-tech innovation. It has been suggested to create 'nursing markets' or 'niches' to protect new technologies from direct competition with the incumbent 
technological system (Geels, 2002; Nemet, 2009). Similarly, niches can be formed to protect embryonic domestic industries from direct competition with foreign manufacturers, using import tariffs, subsidies, localization quota, or preferential treatment in government procurement and private firm contracting (Hoekman et al., 2005; Lewis and Wiser, 2007).

In the design of such stimulus measures, however, governments need to consider that 1 ) these ought to comply with WTO regulations or may otherwise lead to disputes (see Section 3.2.1); 2) that domestic industries can be equally dependent on (barriers to) market entry into foreign markets; and 3) that all too protectionist measures may also limit interaction between foreign and domestic industries and therefore have consequences for technology transfer (see also Sections 3.1.4 and 3.1.6).

Lastly, there is an important element of timing in the enactment of stimulus measures, both in emerging and advanced economies. The potential 'first mover advantage' in new industries will accrue only to those that choose to act quickly, and the enactment of strong support abroad may therefore induce a sense of urgency to act. This notion, when concerning clean-tech, is perhaps best captured in the US 2011 'State of the Union'. More support for renewable energy industries was urged as current global developments were considered a 'sputnik moment' for clean energy. This statement came shortly after the US Energy Secretary had warned of the US falling behind in the clean-tech race, on China and other countries (White House Office of the Press Secretary, 2011).

\subsubsection{Global technology markets}

Apart from the global trade in equipment, other codified forms of technology are traded internationally as well. Such transfers do not necessarily depend on the initiative of transnational corporations or 'lead firms' from advanced economies. Emerging economy firms have often sought to rapidly build up manufacturing capabilities through the purchase or licensing of patents or manufacturing designs. Licensing agreements typically require the licensee to pay a royalty fee to the licensor for every unit of equipment manufactured. Effectively, this allows manufacturing firms in emerging economies to utilize the products of R\&D efforts performed in advanced economies. It should be noted, however, that much technical know-how is required to replicate the production process, and effective transfers are often not complete with just the acquisition of a patent or blueprint (Arora, 1996; Teece, 1981).

Furthermore, firms make careful considerations in what knowledge, and how, they are willing to transfer, as this can induce the risk of creating new competitors (Archibugi and Pietrobelli, 2003; Lewis and Wiser, 2007). Concerns over knowledge spillovers, i.e., undesirably high levels of knowledge transfer, exist in particular with transactions to developing or emerging economies, as these typically have weaker intellectual property rights regimes (Maskus, 2000; Smarzynska Javorcik, 2004). Such considerations will be part of other forms of technology transfers efforts (e.g., in TNC or GPN), and even in selecting export markets for equipment, as 'reverse engineering' may result in knowledge spill-overs as well (Maskus, 2000).

A recent trend in these global technology markets is the merger with or acquisition of advanced economy firms and their intellectual property, by manufacturing oriented firms from emerging economies. This trend challenges the usual power distribution as suggested by the 'flagship plus suppliers' model that dominates GPN literature (Coe et al., 2008; Lewis, 2011). For example, in 2009, the Chinese wind turbine manufacturer Goldwind acquired the German company Vensys, which had served as its source for designs for many years before (Lewis, 2011). Similarly, Suzlon, the leading wind turbine manufacturer from India has been 'shopping' on the global knowledge market for partners for different turbine components (Lewis, 2007). Sufficient market share and build-up of capital allows emerging economy firms to gain more control of global production networks.

\subsubsection{Private and institutional financiers}

Private banking and investment industries are highly internationalized, and may provide finance for the development of economic activities. However, for clean-tech projects in emerging and developing economies, project finance may be relatively difficult to secure, and only at higher interest levels. This is because projects aimed at environmental protection do not necessarily result in very high returns on investment, and because emerging and developing economies may be considered more risky investment destinations.

Concerned with the availability of (affordable) financing for such projects, the international community has created a number of channels to make it available at more affordable rates than do private lenders (Panayotou, 2013). These include the Global Environmental Facility (GEF), World Bank, IMF and Regional Development Banks. Such project finance is often combined with technical assistance (Henderson et al., 2002; Peltier and Ashford, 1998). Loans from these institutions have been used for capacity development, including e.g., in equipment production, as well as for financing deployment of clean-tech solutions (Martinot, 1998; Panayotou, 2013).

\subsubsection{Global industry platforms and environmental groups}

Both the development and the exchange of knowledge are central processes in TIS development (Bergek et al., 2008a; Hekkert et al., 2007). In a systems approach to innovation, the utility of the exchange of knowledge in networks is not limited to purely technical aspects, but includes exchanges between actors from industry, government, advocacy coalitions etc., amongst others, on the current phase of development of the technology and the best way forward (Binz et al., 2012; Hekkert et al., 2007).

Global industry platforms, such as the Global Wind Energy Association, or globally active environmental groups such as Greenpeace, WWF etc., can help in the transnational diffusion of knowledge and creation of legitimacy. They may do so by exchanging insights and building advocacy based on experiences developed elsewhere. This can include information on suitable targets, best (policy) practices, regulatory design etc.

\subsection{Transnational TIS institutions and emerging economy TIS development}

National policies are a crucial part of the institutional framework of TIS, in particular for clean-tech. Concurrently, the 'emerging international economic order is a rules-based system whereby more and more previously national policies become the subject of international regulations' (Radosevic, 1999: p. 433). The most relevant supranational institutions to clean-tech innovation are those governing international trade and intellectual property rights, as well as those governing global efforts for environmental sustainability.

\subsubsection{The World Trade Organization and TRIPS}

The World Trade Organization (WTO) 'provides a forum for negotiating agreements aimed at reducing obstacles to international trade and ensuring a level playing field for all' (WTO, 2014). The two main principles are the reduction of trade barriers (border tax adjustments, or tariffs, as well as non-tariff barriers to trade), and non-discrimination, meaning no differences may exist in the 
treatment of products from any two member states (GATT, 1994a). Virtually all countries are WTO members.

The regulation of international trade is relevant for TIS formation, because the successful development of clean-tech requires government intervention, in the form of e.g., the creation of protected 'niche' markets, subsidies for consumption and/or R\&D, or government procurement that favours environmentally benign alternatives (Bergek et al., 2008b; Nemet, 2009). The WTO principles mean that WTO members, in the design of such stimulus measures, may not discriminate between domestic and foreign products (GATT, 1994a). It is, for example, not allowed to create niche markets for domestic manufacture by levying taxes on imports (tariffs), nor is it allowed to introduce non-tariff barriers to trade, such as import quota. Industrial subsidies are also prohibited when exports disturb foreign markets (dumping), and in the strictest sense of the WTO it is not allowed to provide RD\&D grants, if these are available only to domestic firms (GATT, 1994a).

These restrictions may be more relevant for emerging economies, as these join the competition in global innovation systems in later phases. The more matured industries in advanced economies are likely to be less dependent on government support than the more embryonic industries in emerging economies are. Further, more matured global systems have larger market sizes with increased economic significance. This is likely to lead to increased international scrutiny on government stimulus measures, and this may limit the set of policies available to emerging economy governments to promote emerging domestic innovation systems.

There are, however, four important nuances to the restrictions as laid out by the WTO agreements.

First, many emerging economies have not been WTO member for very long, and new member nations are granted a transition period to comply with WTO rules. China became a WTO member in 2001, but was required to comply with trade barrier rules by 2005 , and broader economic adjustments were evaluated annually for an eight year period (Rumbaugh and Blancher, 2004).

Secondly, although the aim of the WTO is a complete removal of trade barriers between member nations, this is an unfinished process. Membership requirements for China were to reduce tariffs on industrial goods to 'an average of 9 per cent' (Rumbaugh and Blancher, 2004). The expected differences in benefits of full trade liberalization between advanced and emerging or developing economies are a focal point of the debate (Anderson et al., 2006).

Third, some forms of government support are allowed ('nonsanctionable'). Government support can be provided for industrial research and pre-competitive development activities (GATT, 1994a).

Fourth, the WTO has an agreement on government procurement, but few emerging economies, including China, are signatories to this separate agreement and cannot be sanctioned for noncompliance.

WTO members are automatically signatories to the agreement on 'Trade Related aspects of Intellectual Property rightS' (TRIPS). TRIPS stipulates minimum requirements for IPR regulation in member countries, including that foreign firms may register ownership over a patent or industrial design, and that their exclusive ownership will be protected for a period of 20 years (patents) or 10 years (industrial designs) (GATT, 1994b).

\subsubsection{International environmental regimes}

Because many environmental problems are trans-boundary problems, national governments have created international regimes for their management. The collective management of a transnational environmental issue is expected to be more efficient than individual action (List and Rittberger, 1992). Negotiations in such regimes help converge individual parties' expectations of other parties' contributions to achieving a collective goal, i.e., the protection of the global environment (Krasner, 1983). Well known environmental regimes are e.g., the UN's 'Agenda 21', which promotes global sustainable development, and the UNFCCC, which promotes climate change mitigation efforts.

Debate remains on whether or not these global fora actually influence environmental target setting and policy efforts in member countries (Young, 2011). For example, in the climate change regime, a number of emerging economies have opposed emission reduction obligations out of concerns over effects these may have on further economic development. A number of advanced economies have refused cooperation, amongst others because of the regime's lack of binding targets for major emerging economies, and concerns over the effects of emission reduction targets on the international competitiveness of domestic industries (Van Asselt and Brewer, 2010).

\subsubsection{Institutional transfer programmes}

Most clean-tech solutions have high societal value, but limited commercial viability. Their global diffusion via strictly commercial channels (see Sections 3.1.3 through 3.1.6) may therefore be limited. The international community has therefore established initiatives for the global diffusion of 'environmentally sound technologies' to developing and emerging economies, in programmes similar to official development aid (Martinot, 2001; OECD, 2005; Wilkins, 2002). Such programmes can be organized as bilateral aid, through institutional financiers (Section 3.1.7) or as instruments in specific environmental regimes. For instance, both Agenda 21 and the UNFCCC urge developed parties to assist developing parties with technological capacity-building and to create 'favourable access' for the funding of such efforts (UNCED, 1992; UNFCCC, 1992).

The 'Clean Development Mechanism' (CDM), an instrument of the UNFCCC, is probably the most formalized institution for international clean-tech transfers. Under the CDM, 'Annex 1 parties' (circa the advanced economies) may fulfil part of their domestic GHG emission reduction obligations by carrying out reduction projects in non-Annex 1 parties. These projects are required to be 'additional' in the sense that they either introduce technologies that were not previously employed in the host country, and/or would be financially unattractive for private investment without income from carbon emission credits (UNFCCC, 1997). The CDM mechanism creates additional value for emission reduction projects in developing and emerging economies, which spurs market formation, attracts foreign investment, and stimulates the transnational transfers of technologies (Hultman et al., 2012).

It should be noted, however, that these transfer efforts are far more complex than a simple market transaction for a piece of equipment. Successful transfers require sufficient know-how and infrastructure in the recipient environment, e.g., for the operation and maintenance of the technology (OECD, 2005; Wilkins, 2002). Further, such transfers depend on the adaptability of the foreign technology to the broader economic system of the receiving environment, with some types of technology more readily utilized in other domestic contexts. Matches or mismatches of technology and receiving environment can be purely technical, e.g., infrastructural systems or the availability and quality of biomass resources can vary strongly form country to country. A (mis)match of technology and receiving environment can also result from what is labelled the 'direction of the search' in TIS analyses. A specific technological solution reflects specific desires, needs and capabilities of the originating TIS. These do not necessarily match the recipient TIS, and domestic actors have less influence over the direction of the search outside the domestic context (IEA/OECD, 2001; Martinot et al., 2002). These various types of mismatch and adaptability of technology to a receiving environment can be an issue with any 
transfer mechanism, but have been considered a problem with institutionally arranged transfers in particular (Peterson, 2008; Radosevic, 1999).

\subsubsection{Technological standards and certification}

Technological standards can be specified to ensure performance, conformity, and safety of new products and processes, as well as interoperability among systems (Allen and Sriram, 2000). Technological standards are not necessarily discussed and agreed upon at the global level. Rather, technological standardization is often driven by technological leaders, and requires firms from emerging economies to adhere to these in order to compete in export markets (Allen and Sriram, 2000; Yoo et al., 2005).

Standards themselves may also diffuse internationally; China, for instance, has adopted the EURO norms for vehicle emissions, rather than developing its own standards (Rousselin, 2012).

Conforming to existing standards in export markets or the adoption of these domestically can help shortcut some TIS development. In TIS terminology, standardization is connected with the direction of the search, and their transnational diffusion implies that TIS development in the adopting domestic context is influenced by considerations leading to the development of the standard elsewhere.

Similar to the diffusion of standards, and strongly connected with these in the case of quality standards, is the existence of globally recognized quality control and certification. For example, TÜV Nord's director stated that there was 'considerable demand for internationally-recognized certification in China', when it was hired to certify a wind turbine by Sinovel (Windpower Offshore, 2012). TÜV's international reputation is the likely reason why Sinovel chose it over domestic certification bodies such as the China Quality Certification Centre (CQC). Such certification can spur emerging economy TIS development as these do not necessarily have to develop certification bodies, or their global reputation, in order to acquire globally recognized quality certification.

\subsection{Summary overview: transnational dimensions and emerging economy TIS development}

In Table 1, we summarize Sections 3.1 and 3.2 in an overview of transnational dimensions and their effects on emerging economy TIS development. These dimensions are categorized according to the TIS functions that they affect. Note that this is not necessarily a one-to-one relationship: different transnational structures may concurrently affect a number of different TIS functions.

\section{Relevance for policy making}

The TIS framework is primarily designed to produce policy recommendations for technology development and diffusion in relation to energy, climate and environmental policies (Bergek et al., 2008b; see also Fig. 3). System weaknesses, revealed as poorly performed TIS functions, help to target policy interventions. Policy makers concerned with the design of national policy goals for a specific technological field ought to take into account the fact that the domestic TIS is a sub-system of a TIS that exists at the global level, and that the two interact. This has two important implications for domestic policy.

First, this implies that not all TIS functions necessarily need to be performed to a high degree in the domestic context. Domestic innovative activity may rely on the global TIS for functions that are weakly performed, and contribute to global TIS development with functions that are strongly performed within the domestic context. As such, domestic TIS can be more or less 'specialized' in terms of the functions they perform within the global TIS. Specific forms of
TIS specialization may be limited by domestic capacities, but strategic policy choices matter as well. For instance, policy can set environmental targets with or without a combined policy strategy for the development of a domestic industry; equipment can also be imported. Domestic industries may be developed largely for the fulfilment of domestic demand for clean-tech equipment, or for export markets, and policy may pursue either more manufacturing or knowledge intensive phases in the production process.

Second, policy makers should take into account that transnational TIS actor-networks and institutions may induce, or in some cases block, domestic TIS development, as elaborated in Section 3. Specific policy arrangements may help maximize inducement and mitigate blocking effects of transnational TIS dimensions on the development of the domestic TIS.

A number of specific policy recommendations for emerging economy TIS can be derived from insights of the results presented in Section 3.

First, governments of emerging economies should encourage firm-to-firm knowledge exchanges. Governments may encourage such cooperation by reducing restrictions on foreign investment in certain sectors, with tax incentives or even demands for certain forms of cooperation or technology transfer deals (Fu et al., 2011).

Second, emerging economy governments also have an important role in improving the regulatory framework for IPR protection. This reduces the reluctance of foreign firms to transfer key technologies to these emerging economies, but will also have beneficial effects on domestic R\&D efforts (Maskus, 2000; Zhao, 2006).

Third, skilled individuals can be encouraged to return, by providing benefit packages to returnees. This can include headhunting programmes for key positions in industry, government and science, smoother visa procedures for talented individuals and their families, attractive research funds and high financial compensation (Cao, 2008; Saxenian, 2005).

Fourth, technology roadmaps should account for the development of the technological field at the global level, and set realistic goals for domestic TIS development. For example, the Chinese government funded a number of research projects for domestically developed wind turbines, aiming to have $200 \mathrm{~kW}$ machines ready for market by the late nineties (CACETC, 2000; Ru et al., 2012). By then, $600 \mathrm{~kW}$ machines had become the norm in global markets, and domestic market supply was dominated by foreign manufacturers (GWEC, 2007; Ru et al., 2012). From the early '00s onwards, a number of domestic manufacturers became successful competitors in this market; all of these offered turbines on the basis of licenses from foreign designers (Gosens and Lu, 2014). The reality of highly globalized markets is therefore a double-edged sword for TIS development in emerging economies. Building a domestic industry for clean-tech equipment can be a lengthy, difficult, and costly learning process (Ernst, 2002), and this process can be short-cut by using alternatives available from the global TIS. Doing so, however, may also suppress the development of a domestic equipment manufacturing industry (in case of equipment imports) or a domestic knowledge developers (in case of technology imports).

Lastly, this policy strategy should be dynamic. Crucially, the term 'emerging' does not describe a static developmental status, but rather an evolution from lagging behind to closing in on the global technological forefront. Policy should therefore consider the changing nature of the relationship between domestic and global TIS elements over time. Again, the Chinese wind turbine industry is a good example. This industry has grown to dominate domestic markets, and currently a number of the world's biggest manufacturers are from China (GWEC, 2013). Chinese policy makers realize that this industry has been built up on the basis of imported foreign knowledge, however, and are now seeking to fix this imbalance. China's latest plan for innovation seeks to improve 
'indigenous' and independent innovative capacities, with control over key IPR (State Council of P.R. China, 2012). Amongst others, the plan aims for better integration between domestic institutes and universities and domestic manufacturing industries, a link that has poorly developed with the large dependency for technology on the global TIS.

\section{Conclusion and discussion}

The development of TIS in emerging economies is heavily influenced by transnational dimension in TIS actor-networks and TIS institutions. Analyses of emerging economy TIS using a strict national delineation run the risk of externalizing a set of factors highly important to innovation system development. For cleantech in particular, there are a number of institutions that seek to spur global diffusion to developing and emerging economies, increasing the relevance of these transnational dimensions.

These transnational dimensions have been largely absent from the current body of empirical TIS work on advanced economies, where these can be expected to have lesser relevance. We did not, however, find a need to include more or different functions in order to appropriately grasp the issues that frustrate or spur clean-tech innovation in emerging economies. The potential effects of transnational dimensions on emerging economy TIS development could all be categorized using the original list of seven system functions as identified by Bergek et al. (2008b).

This gives two inroads for future investigation. Firstly, the existing literature on innovation in emerging economies has used rather generic concepts such as 'improving absorptive capacity' and 'industrial upgrading' to describe the mechanisms for improving innovation system functioning. The system functions of the TIS framework could offer more analytical grasp when describing advances in innovative activity in emerging economies. Secondly, analysts have been in search of possible 'typical' system failures (for certain categories of technologies) and policy issues that are most pertinent in each phase of TIS maturation (e.g., del Río and Bleda, 2012; Foxon and Pearson, 2008; Negro et al., 2010; van Alphen et al., 2009). Both of these lines of investigation would offer insights into commonalities in TIS formation mechanisms across different TIS.

Although we found that the same set of functions may be used to analyze emerging economy TIS, we would require a fair number of empirical applications before we could comment on differences or commonalities in system formation or system failures with those found in advanced economy case studies. Specifically, the identification of a list of transnational dimensions (Table 1) does not include statements as to which of these were found to be more commonly present, or more important. The scarcity of TIS based empirical work on clean-tech innovation in emerging economies, in contrast with their fast increasing contribution to global environmental pressure and innovative activity, certainly justifies such attention.

We have focused on the role of transnational dimensions in TIS formation in emerging economies, but there is evidence of their relevance for advanced economies as well, especially in more mature global TIS. The formation of TIS for both first and second generation biofuels for transport is subject to a well-developed global market for biofuels, with biofuel production concentrated in a small number of countries (Lamers et al., 2011; Raman and Mohr). The Dutch wind power TIS is often perceived as having failed to mature due to the lack of a domestic manufacturing industry (e.g., Kamp et al., 2004). Nevertheless, 3.5 per cent of Dutch electricity consumption is wind power (CBS Statline, 2012), and the Netherlands has a number of design houses, e.g. Darwind B.V., STX Windpower B.V. and EWT International, that supply to foreign manufacturers. This would not have been possible without transnational linkages with a vibrant global TIS.

In conclusion, in our search for transnational dimensions in the TIS framework, we have zoomed in on the linkages between the national and the global. Other work on the geography of innovation has stressed the importance of regions or clusters, and how these may form the nodes for globally connected innovation systems (Chaminade, 2011; Chaminade and Vang, 2008; Coe et al., 2004). The most proper geographic delineation of innovation systems will probably remain subject of discussion for some time, and is likely always dependent on the sort of analysis made. As for national borders, our framework concurs with the notion that these do not confine technology, but this should not be confused to imply that national borders are of no relevance in global TIS formation patterns.

\section{Acknowledgements}

The authors gratefully acknowledge the assistance of Prof. Dr. T.A.M. Beckers, professor at the Tilburg Sustainability Center, Tilburg University, The Netherlands, and visiting professor at the Research Center for Eco-Environmental Sciences, Chinese Academy of Sciences, Beijing, China during May-July 2012, for valuable comments on a previous manuscript. Jorrit Gosens received financial support through a Foreign Student Scholarship from the Graduate University of the Chinese Academy of Sciences, and from the Chalmers Environmental Initiative. Lars Coenen gratefully acknowledges financial support from the Swedish Research Council and VINNOVA to carry out this research.

\section{References}

Abramovitz, M., 1986. Catching up, forging ahead, and falling behind. J. Econ. Hist. 46, 385-406.

Allen, R.H., Sriram, R.D., 2000. The role of standards in innovation. Technol. Forecast. Soc. Change 64, 171-181.

Amin, A., 2002. Spatialities of globalisation. Environ. Plan. A 34, 385-399.

Anderson, K., Martin, W., van der Mensbrugghe, D., 2006. Doha merchandise trade reform: what is at stake for developing countries? World Bank Econ. Rev. 20, $169-195$.

Archibugi, D, Pietrobelli, C, 2003. The globalisation of technology and its implications for developing countries: windows of opportunity or further burden? Technol. Forecast. Soc. Change 70, 861-883.

Arora, A., 1996. Contracting for tacit knowledge: the provision of technical services in technology licensing contracts. J. Dev. Econ. 50, 233-256.

Bai, X., Wieczorek, A.J., Kaneko, S., Lisson, S., Contreras, A., 2009. Enabling sustainability transitions in Asia: the importance of vertical and horizontal linkages. Technol. Forecast. Soc. Change 76, 255-266.

Bergek, A., Hekkert, M., Jacobsson, S., 2008a. Functions in innovation systems: a framework for analysing energy system dynamics and identifying goals for system-building activities by entrepreneurs and policymakers. In: Foxon, T.J., Köhler, J., Oughton, C. (Eds.), Innovation for a Low Carbon Economy Economical, Institutional and Management Approaches. Edward Elgar, Cheltenham and Northampton, pp. 79-111.

Bergek, A., Jacobsson, S., Carlsson, B., Lindmark, S., Rickne, A., 2008b. Analyzing the functional dynamics of technological innovation systems: a scheme of analysis. Res. Policy 37, 407-429.

Berkhout, F., Verbong, G., Wieczorek, A.J., Raven, R., Lebel, L., Bai, X., 2010. Sustainability experiments in Asia: innovations shaping alternative development pathways? Environ. Sci. Policy 13, 261-271.

Binz, C., Truffer, B., Coenen, L., 2014. Why space matters in technological innovation systems-mapping global knowledge dynamics of membrane bioreactor technology. Res. Policy 43, 138-155.

Binz, C., Truffer, B., Li, L., Shi, Y., Lu, Y., 2012. Conceptualizing leapfrogging with spatially coupled innovation systems: the case of onsite wastewater treatment in China. Technol. Forecast. Soc. Change 79, 155-171.

Blomström, M., Sjöholm, F., 1999. Technology transfer and spillovers: does local participation with multinationals matter? Eur. Econ. Rev. 43, 915-923.

Brandt, U.S., Svendsen, G.T., 2006. Climate change negotiations and first-mover advantages: the case of the wind turbine industry. Energy Policy 34, 1175-1184.

CACETC, 2000. China Wind Power - Study Report. As Part of UNFCCC Technological Needs Assessment.

Cantwell, J., 1991. The theory of technological competence and its application to international production. In: McFetridge, D. (Ed.), Foreign Investment, Technology and Economic Growth. University of Calgary Press, Calgary. 
Cao, C., 2008. China's brain drain at the high end. Asian Popul. Stud. 4, 331-345.

Carlsson, B., 2006. Internationalization of innovation systems: a survey of the literature. Res. Policy 35, 56-67.

Carlsson, B., Stankiewicz, R., 1991. On the nature, function and composition of technological systems. J. Evol. Econ. 1, 93-118.

CBS Statline, 2012. Dutch Online Statistics Database. Accessible via. statline.cbs.nl/ StatWeb/?LA=en (last accessed 30.08.12.).

Chaminade, C., 2011. Exploring the Role of Regional Innovation Systems and Institutions in Global Innovation Networks. CIRCLE working paper 2011/15.

Chaminade, C., Vang, J., 2008. Globalisation of knowledge production and regional innovation policy: supporting specialized hubs in the Bangalore software industry. Res. Policy 37, 1684-1696.

Coe, N.M., Dicken, P., Hess, M., 2008. Global production networks: realizing the potential. J. Econ. Geogr. 8, 271-295.

Coe, N.M., Hess, M., Yeung, H.W.-c., Dicken, P., Henderson, J., 2004. 'Globalizing' regional development: a global production networks perspective. Trans. Inst. Br. Geogr. 29, 468-484.

Coenen, L., Benneworth, P., Truffer, B., 2012. Toward a spatial perspective on sustainability transitions. Res. Policy 41, 968-979.

Cohen, W., Levinthal, D., 1990. Absorptive capacity: a new perspective on learning and innovation. Adm. Sci. Q. 35, 128-152.

del Río, P., Bleda, M., 2012. Comparing the innovation effects of support schemes for renewable electricity technologies: a function of innovation approach. Energy Policy 50, 272-282.

Ernst, D., 2002. Global production networks and the changing geography of innovation systems. Implications for developing countries. Econ. Innov. New Technol. 11, 497-523.

Ernst, D., Kim, L., 2002. Global production networks, knowledge diffusion, and local capability formation. Res. Policy 31, 1417-1429.

Foxon, T., Pearson, P., 2008. Overcoming barriers to innovation and diffusion of cleaner technologies: some features of a sustainable innovation policy regime. J. Clean. Prod. 16, S148-S161.

Freeman, C., 1987. Technology, Policy, and Economic Performance: Lessons from Japan. Pinter Publishers, London.

Freeman, C., 1995. The 'national system of innovation' in historical perspective. Camb. J. Econ. 19, 5-24.

Fu, X., Pietrobelli, C., Soete, L., 2011. The role of foreign technology and indigenous innovation in the emerging economies: technological change and catching-up. World Dev. 39, 1204-1212.

GATT, 1994a. Agreement on Subsidies and Countervailing Measures.

GATT, 1994b. Agreement on Trade-Related Aspects of Intellectual Property Rights, Including Trade in Counterfeit Goods.

Geels, F.W., 2002. Technological transitions as evolutionary reconfiguration processes: a multi-level perspective and a case-study. Res. Policy 31, 1257-1274.

Gereffi, G., Fernandez-Stark, K., 2011. Global Value Chain Analysis: a Primer. Center on Globalization, Governance \& Competitiveness.

Gereffi, G., Humphrey, J., Sturgeon, T., 2005. The governance of global value chains. Rev. Int. Polit. Econ. 12, 78-104.

Gosens, J., Lu, Y., 2013. From lagging to leading? Technological innovation systems in emerging economies and the case of Chinese wind power. Energy Policy 60, $234-250$.

Gosens, J., Lu, Y., 2014. Prospects for global market expansion of China's wind turbine manufacturing industry. Energy Policy 67, 301-318.

GWEC (Global Wind Energy Council), 2007. China Wind Power Report 2007.

GWEC (Global Wind Energy Council), 2013. Global Wind Report (Several Years Used).

Hansen, J.A., Lehmann, M., 2006. Agents of change: universities as development hubs. J. Clean. Prod. 14, 820-829.

Hansen, U.E., Nygaard, I., 2013. Transnational linkages and sustainable transitions in emerging countries: exploring the role of donor interventions in niche development. Environ. Innov. Soc. Transit. 8, 1-19.

Hekkert, M.P., Suurs, R.A.A., Negro, S.O., Kuhlmann, S., Smits, R.E.H.M., 2007. Functions of innovation systems: a new approach for analysing technological change. Technol. Forecast. Soc. Change 74, 413-432.

Henderson, J., Dicken, P., Hess, M., Coe, N., Yeung, H.W.-C., 2002. Global production networks and the analysis of economic development. Rev. Int. Polit. Econ. 9, 436-464.

Hoekman, B.M., Maskus, K.E., Saggi, K., 2005. Transfer of technology to developing countries: unilateral and multilateral policy options. World Dev. 33, 1587-1602.

Hultman, N.E., Pulver, S., Guimarães, L., Deshmukh, R., Kane, J., 2012. Carbon market risks and rewards: firm perceptions of CDM investment decisions in Brazil and India. Energy Policy 40, 90-102.

IEA, 2010. $\mathrm{CO}_{2}$-Emissions from Fuel Combustion. OECD/IEA, Paris.

IEA/OECD, 2001. Technology without Borders - Case Studies of Successful Technology Transfer. IEA/OECD, Paris.

Inkpen, A.C., 2000. Learning through joint ventures: a framework of knowledge acquisition. J. Manag. Stud. 37, 1019-1044.

IPCC, 2007. In: Metz, B., Davidson, O.R., Bosch, P.R., Dave, R., Meyer, L.A. (Eds.), Contribution of Working Group III to the Fourth Assessment Report of the Intergovernmental Panel on Climate Change. Cambridge University Press, Cambridge, United Kingdom and New York, NY.

Jacobsson, S., Bergek, A., 2011. Innovation system analyses and sustainability transitions: contributions and suggestions for research. Environ. Innov. Soc. Transit. $1,41-57$.
Kamp, L.M., Smits, R.E.H.M., Andriesse, C.D., 2004. Notions on learning applied to wind turbine development in the Netherlands and Denmark. Energy Policy 32, $1625-1637$.

Keely, C.B., 1986. Return of talent programs: rationale and evaluation criteria for programs to ameliorate a ‘brain drain'. Int. Migr. 24, 179-189.

Kim, L., 1997. Imitation to Innovation: the Dynamics of Korea's Technological Learning. Harvard Business School Press, Boston, MA.

Kinoshita, Y., 2000. R\&D and Technology Spillovers via FDI: Innovation and Absorptive Capacity.

KPMG, D., EUPD Research, 2013. Cleantech-standortgutachten 2013 (in German; English summary). Available via: dcti.de/en/cleantech/definition.html.

Krasner, S.D., 1983. Structural causes and regime consequences: regimes as intervening variables. In: Krasner, S.D. (Ed.), International Regimes. Cornell University Press, Ithaca, NY and London.

Lall, S., 1996. Learning from the Asian Tigers: Studies in Technology and Industrial Policy. Palgrave Macmillan, London.

Lamers, P., Hamelinck, C., Junginger, M., Faaij, A., 2011. International bioenergy trade-a review of past developments in the liquid biofuel market. Renew. Sustain. Energy Rev. 15, 2655-2676.

Lema, R., Lema, A., 2012. Technology transfer? The rise of China and India in green technology sectors. Innov. Dev. 2, 23-44.

Levy, D.L., 2008. Political contestation in global production networks. Acad. Manag. Rev. 33, 943-963.

Lewis, J.I., 2007. Technology acquisition and innovation in the developing world: wind turbine development in China and India. Stud. Comp. Int. Dev. 42 $208-232$.

Lewis, J.I., 2011. Building a national wind turbine industry: experiences from China, India and South Korea. Int. J. Technol. Glob. 5, 281-305.

Lewis, J.I., Wiser, R.H., 2007. Fostering a renewable energy technology industry: an international comparison of wind industry policy support mechanisms. Energy Policy 35, 1844-1857.

List, M., Rittberger, V., 1992. Regime theory and international environmental management. In: Hurrell, A., Kingsbury, B. (Eds.), The International Politics of the Environment. Clarendon Press, Oxford, pp. 85-109.

Løvdal, N., Neumann, F., 2011. Internationalization as a strategy to overcome industry barriers - an assessment of the marine energy industry. Energy Policy 39. 1093-1100.

Lundvall, B.-A., 1992. National Systems of Innovation: towards a Theory of Innovation and Interactive Learning. Pinter Publishers, London.

Lundvall, B.-Å., Johnson, B., Andersen, E.S., Dalum, B., 2002. National systems of production, innovation and competence building. Res. Policy 31, 213-231.

Markard, J., Truffer, B., 2008. Technological innovation systems and the multi-level perspective: towards an integrated framework. Res. Policy 37, 596-615.

Martinot, E., 1998. Monitoring and Evaluation of Market Development in World Bank-GEF Climate Change Projects: Framework and Guidelines. Global Environment Division.

Martinot, E., 2001. Renewable energy investment by the World Bank. Energy Policy 29, 689-699.

Martinot, E., Chaurey, A., Lew, D., Moreira, J.R., Wamukonya, N., 2002. Renewable energy markets in developing countries. Annu. Rev. Energy Environ. 27, 309-348.

Martinot, E., Sinton, J.E., Haddad, B.M., 1997. International technology transfer for climate change mitigation and the cases of Russia and China. Annu. Rev. Energy Environ. 22, 357-401.

Maskus, K.E., 2000. Intellectual Property Rights in the Global Economy. Peterson Institute.

Mohamad, Z.F., 2011. The emergence of fuel cell technology and challenges for catching-up by latecomers: insights from Malaysia and Singapore. Int. J. Technol. Glob. 5, 306-326.

Negro, S.O., Hekkert, M., Alkemade, F., 2010. Seven Typical System Failures that Hamper the Diffusion of Sustainable Energy Technologies. Paper presented at the Druid Summer Conference 2010.

Nelson, R., 1993. National Innovation Systems: a Comparative Analysis. Oxford University Press, New York, NY and Oxford.

Nemet, G.F., 2009. Demand-pull, technology-push, and government-led incentives for non-incremental technical change. Res. Policy 38, 700-709.

Ockwell, D.G., Watson, J., MacKerron, G., Pal, P., Yamin, F., 2008. Key policy considerations for facilitating low carbon technology transfer to developing countries. Energy Policy 36, 4104-4115.

OECD, 2005. Achieving the Successful Transfer of Environmentally Sound Technologies: Trade Related Aspects. OECD trade and environment working paper no. 2005-02. OECD, Paris.

OECD, 2011. Invention and Transfer of Environmental Technologies, OECD Studies on Environmental Innovation. OECD Publishing.

OECD, 2014. Online Glossary of Statistical Terms, Definition of Clean Technology. https://stats.oecd.org/glossary/detail.asp? ID =2988.

Panayotou, T., 2013. Instruments of Change: Motivating and Financing Sustainable Development. Routledge.

Peltier, N.-P., Ashford, N.A., 1998. Assessing and rationalizing the management of a portfolio of clean technologies: experience from a French environmental fund and a World Bank Cleaner Production demonstration project in China. J. Clean. Prod. 6, 111-117.

Peterson, S., 2008. Greenhouse gas mitigation in developing countries through technology transfer?: a survey of empirical evidence. Mitig. Adapt. Strateg. Global Change 13, 283-305. 
Radosevic, S., 1999. International technology transfer policy: from "contract bargaining" to "sourcing". Technovation 19, 433-444.

Raman, S., Mohr, A., 2014. Biofuels and the role of space in sustainable innovation journeys. J. Clean. Prod. 65, 224-233.

REN21, 2013. Renewables 2013 Global Status Report. REN21 Secretariat, Paris.

Rennings, K., 2000. Redefining innovation-eco-innovation research and the contribution from ecological economics. Ecol. Econ. 32, 319-332.

Rosenberg, N., Frischtak, C., 1985. International Technology Transfer - Concepts, Measures and Comparisons. Praeger, New York.

Rousselin, M., 2012. But why would they do that? European external governance and domestic preferences of rule importers. J. Contemp. Eur. Res. 8, 470-489.

Ru, P., Zhi, Q., Zhang, F., Zhong, X., Li, J., Su, J., 2012. Behind the development of technology: the transition of innovation modes in China's wind turbine manufacturing industry. Energy Policy 43, 58-69.

Rumbaugh, T., Blancher, N., 2004. China: International Trade and WTO Accession. IMF working paper WP/04/36.

Saxenian, A., 2002. Transnational communities and the evolution of global production networks: the cases of Taiwan, China and India. Ind. Innov. 9, 183-202.

Saxenian, A., 2005. From brain drain to brain circulation: transnational communities and regional upgrading in India and China. Stud. Comp. Int. Dev. 40, 35-61.

Smarzynska Javorcik, B., 2004. The composition of foreign direct investment and protection of intellectual property rights: evidence from transition economies. Eur. Econ. Rev. 48, 39-62.

State Council of P.R. China, 2012. Opinions on Deepening Technological System Reform and Accelerating the Construction of a National Innovation System.

Suurs, R.A.A., Hekkert, M.P., 2009. Cumulative causation in the formation of a technological innovation system: the case of biofuels in the Netherlands. Technol. Forecast. Soc. Change 76, 1003-1020.

Teece, D.J., 1977. Technology transfer by multinational firms: the resource costs of transferring technical know-how. Econ. J. 87, 242-261.

Teece, D.J., 1981. The market for know-how and the efficient international transfer of technology. Ann. Am. Acad. Polit. Soc. Sci. 458, 81-96.

Teece, D.J., 2001. Firm capabilities and economic development: implications for the newly industrializing economies. In: Kim, L., Nelson, R.R. (Eds.), Technology Learning and Innovation: Experiences of Newly Industrializing Economies. Cambridge University Press, Cambridge.

Truffer, B., 2012. The need for a global perspective on sustainability transitions. Env Dev. 3, 182-183.

UNCED, 1992. Agenda 21: the United Nations Program of Action from Rio.

UNCTAD, 2014. Definition of 'Transnational Corporations (TNC)'. http://unctad.org en/Pages/DIAE/Transnational-corporations-(TNC).aspx.
UNFCCC, 1992. United Nations Framework Convention on Climate Change.

UNFCCC, 1997. Kyoto Protocol to the United Nations Framework Convention on Climate Change.

van Alphen, K., Hekkert, M.P., Turkenburg, W.C., 2009. Comparing the development and deployment of carbon capture and storage technologies in Norway, the Netherlands, Australia, Canada and the United States - an innovation system perspective. Energy Procedia 1, 4591-4599.

van Alphen, K., Hekkert, M.P., van Sark, W.G.J.H.M., 2008. Renewable energy technologies in the Maldives-realizing the potential. Renew. Sustain. Energy Rev. $12,162-180$.

Van Asselt, H., Brewer, T., 2010. Addressing competitiveness and leakage concerns in climate policy: an analysis of border adjustment measures in the US and the EU. Energy Policy 38, 42-51.

Vasseur, V., Kamp, L.M., Negro, S.O., 2013. A comparative analysis of photovoltaic technological innovation systems including international dimensions: the cases of Japan and the Netherlands. J. Clean. Prod. 48, 200-210.

Viotti, E.B., 2002. National learning systems: a new approach on technological change in late industrializing economies and evidences from the cases of Brazil and South Korea. Technol. Forecast. Soc. Change 69, 653-680.

Watson, J., Sauter, R., 2011. Sustainable innovation through leapfrogging: a review of the evidence. Int. J. Technol. Glob. 5, 170-189.

White House Office of the Press Secretary, 2011. Remarks by the President in State of Union Address (online transcript).

Wilkins, G., 2002. Technology Transfer for Renewable Energy: Overcoming Barriers in Developing Countries. Earth Scan, London.

Windpower Offshore, 12/7/2012. TÜV Nord to Certify Sinovel Offshore Turbine.

World Bank, 2011. Global Development Horizons 2011 - Multipolarity. The New Global Economy, Washington, D.C.

Worrell, E., van Berkel, R., Fengqi, Z., Menke, C., Schaeffer, R.O., Williams, R., 2001. Technology transfer of energy efficient technologies in industry: a review of trends and policy issues. Energy Policy 29, 29-43.

WTO (World Trade Organization), 2014. WTO Mission Statement. http://www.wto. org/english/thewto_e/whatis_e/wto_dg_stat_e.htm.

Yoo, Y., Lyytinen, K., Yang, H., 2005. The role of standards in innovation and diffusion of broadband mobile services: the case of South Korea. J. Strateg. Inf. Syst. $14,323-353$.

Young, O.R., 2011. Effectiveness of international environmental regimes: existing knowledge, cutting-edge themes, and research strategies. Proc. Natl. Acad. Sci. U.S.A. 108, 19853-19860.

Zhao, M., 2006. Conducting R\&D in countries with weak intellectual property rights protection. Manag. Sci. 52, 1185-1199. 